\title{
Risk Distribution Strategy: An Alternative Solution for Global Supply Chain Risk Management
}

\section{Banomyong Ruth, Yingvilasprasert Montira*}

Faculty of Commerce and Accountancy, Thammasat University, Thailand.

*Corresponding author: E-mail: montira.yin@thammasat.net

\begin{abstract}
In the competitive world, the increase in global activity raises the probability of risk occurrences. It is therefore necessary for firms to develop and implement highly effective risk management program. A systematic review of risk management literature observed that one particular strategy in supply chain management has not been widely discussed. This strategy is called "Risk distribution". It has been widely accepted in other on related disciplines where risk management is prevalent. The purpose of this manuscript is to explore the concept of risk distribution strategy from an academic and business perspective in order to understand its characteristics and to investigate its implication on supply chain management. The results indicate that risk distribution is a potential alternative risk management strategy where focal firms can spread risk or loss to capable risk receivers. Risk distribution can be deployed when firms have no risk management resource but need immediate action with regards to supply chain threats. However, the strategy requires close collaboration between supply chain members in order to reduce conflict areas.
\end{abstract}

Keywords: Risk distribution, Risk management strategy, Supply chain risk management, Systematic review.

\section{Introduction}

The rapid growth in global activity is raising the opportunity of risk occurrences in global supply chains. These risks usually break up supply chain flow and causes supply chain vulnerability [1, 2]. To prevent and reduce such risk occurrence, supply chain risk management theory has proposed a number of models to systematically manage and control risk in the supply chain, both domestically and at the global level. Supply chain risk management has been widely researched in the supply chain literature in recent years $[1,2,3]$ and is derived from supply chain management and risk management [4, 5].Managing risk in global network is not easy. Manuj and Menzter developed a framework to describe how firms could achieve risk management on global manner [2]. The proposed framework contains five main activities: (1) risk identification, (2) risk assessment and evaluation, (3) risk management strategies, (4) implementation of supply chain risk management strategies, and (5) mitigation of supply chain risks. In activity three and four, firms have to select the strategy that is best suited to respective risk characteristics. Otherwise, risks will not be effectively mitigated from firms. In the literature, many interesting response strategies were suggested such as risk postponement, risk hedging, risk diversification, and risk security $[2,6,7,8]$. However, the number of academic references related to risk distribution was limited when comparing to others $[9,10,11$, 12].Risk distribution is a well-known strategy in other disciplines such as finance, medical science, and the legal filed $[13,14]$. In those disciplines, risk distribution is considered an effective and proactive approach to manage risks. The purpose of this manuscript is therefore to better understand this risk management strategy, what are its characteristics and its implication on supply chain management. The manuscript begins with a review of the literature on global supply chain risk management that sets the context under study. The concept of risk distribution is then described through a multidisciplinary systematic review of other disciplines. The results are then analyzed to propose how risk distribution strategy can be formulated for global supply chain risk management.

\section{Global Supply Chain Risk Management}

Manuj and Mentzer developed a framework to explain risk management activities on a global scale [2]. The proposed framework contained five steps: (1) risk identification, (2) risk assessment and evaluation, (3) risk management strategies, (4) implementation of supply chain risk management strategies, and (5) mitigation of supply chain risks. Risk identification is the first 
step in global supply chain risk management. Risk identification is there to source and define characteristics of risk that may impact business performance, both domestically and globally [2, 15]. There exist numerous risk types in supply chains such as (1) supply risk - risks from suppliers, (2) operational risk - risks within organization, (3) demand risk - risks from customers, and (4) information risk - risks from information exchange and flow [2, 16, 17]. These risks can be caused by the same source but may impact on different areas. The second step is to assess those risks being identified in the aforementioned step. Assessing risks facilitates firm to prioritize which risk should be firstly managed [18]. This is very helpful for firms needing to focus on certain key risks when developing their mitigation strategies with limited resource and time [19]. Risks can be quantified based on a simple formula $\mathrm{R}=\mathrm{P} \times \mathrm{I}$, where $\mathrm{R}=$ risk exposure, $\mathrm{P}=$ risk probability, and $\mathrm{I}=$ severity of consequences $[15,20,21,22,23,24$, $25,26]$. High $\mathrm{R}$ value means high risk exposure and therefore the most impact to firm. Step three to five are developed for the risk response stage. Risk response is the process of designing and selecting the most appropriate strategy for risk management [1]. The framework suggested six risk management strategies [2], which includes:

- Risk avoidance - to reduce risk event to zero and/or reduce probability and likelihood to occur for risk events,

- Risk postponement - to adjust supply regarding to demand uncertainty,

- Risk speculation - to select risk taking and concern the anticipation of future demand,

- Risk hedging - to hedge for distributing portfolio of suppliers in order to increase option for decision making,

- Risk control/ Risk share/ Risk transfer - to the increase ability of supply chain member to control processes and systems, and

- Risk security - to make sure that there is security system to protect information.

These strategies have been implemented through different drivers, approaches, management resources, and expected outcomes. Choosing the right risk management strategy can save both time, cost and increase the resilience of the global supply chain [1, 27].

\section{A Systematic Review of Risk Distribution}

The systematic review method was initially developed from medical science in order to synthesize research findings in a systematic, transparent, and reproducible manner [28]. This review method is a good starting point to systematically study previous research articles based on a process approach. Transfield, Denyer, and Smart demonstrated that the systematic review could also be used in the management field. Systematic review for management researches is suggested as shown in Table 1 [28].

In this case, this manuscript applies the 10 phases for reviewing prior relevant literature. The description hereunder illustrates the various stages. This manuscript also follows David and Thomson, et al. and Bekelman, Li, and, Gross [29, 30], whose research were conducted through a clear systematic review process. Although it was observed that a large literature on supply chain risk management strategies, only a few studies explicitly looked into the concept of risk distribution [9-12]. The authors examined peerreviewed journals and the existing grey literature from 1940 until June 2012. The grey literature is a literature that also includes any unpublished manuscripts that are not from academic journals. The authors conducted the systematic review through the Google scholar database by using key words of "Risk distribution" and "Distribution of risk" fixed for topic search. This database was selected because it is able to provide a wide range of manuscripts such as proceedings, white paper, concept papers as well as published academic articles. The database offered 85 studies related to risk distribution strategy. Table 2 summarizes those studies by publication area. It was observed that the study of risk distribution has increased from year to year and the majority of publications are relatively recent from 2007 to June 2011.From this systematic review, it is observed that risk distribution is not a new concept or even terminology. The first observed publication was the one done by Steyer in 1940 [31]. His article highlighted the impact of risk distribution on firms that had to compensate their staff. The majority of research articles mostly focused on characteristics and impacts of risk distribution rather than explaining its scope and coverage [3237]. The main definition that is the most widely cited was proposed by Calabresi [67]. His manuscript entitled: "Some Thoughts on Risk Distribution and the Law of Torts" explained three levels of meaning related to risk distribution.

- A spreading of losses,

- Burden of losses to be borne by those classes of people "most able" to pay, and

- Those firms who could support a loss should bear the burden.

These meanings have been used to identify risk distribution in the examination of legal cases and to help finalize the liability of each responsible party. Medical science is the discipline that referred to risk distribution the most, followed by 
finance and natural science. These three disciplines represents up to $64 \%$ of the studied literature. The majority of the 85 observed publications related to risk distribution described the characteristics of risk distribution in a similar way. Risk distribution is referred to as the

Table 1: Stages of systematic review

\begin{tabular}{|c|c|}
\hline Stage & Phase \\
\hline \multirow{3}{*}{$\begin{array}{l}\text { Stage } 1 \\
\text { Planning the review }\end{array}$} & Phase 0 -Identification for the need for a review \\
\hline & Phase 1 - Preparation of a proposal for a review \\
\hline & Phase 2-Development of a review protocol \\
\hline \multirow{5}{*}{$\begin{array}{l}\text { Stage } 2 \\
\text { Conducting a review }\end{array}$} & Phase 3 - Identification of research \\
\hline & Phase 4 -Selection of studies \\
\hline & Phase 5 - Study quality assessment \\
\hline & Phase 6 - Data extraction and monitoring \\
\hline & Phase 7 - Data synthesis \\
\hline \multirow{2}{*}{$\begin{array}{l}\text { Stage } 3 \\
\text { Reporting \& dissemination }\end{array}$} & Phase 8 - The report and recommendation \\
\hline & Phase 9 - Getting evidence into practice \\
\hline
\end{tabular}

Source: Tranfield, Denyer, and Smart (2003)

Table 2: Number of risk distribution publications (as of June 2012)

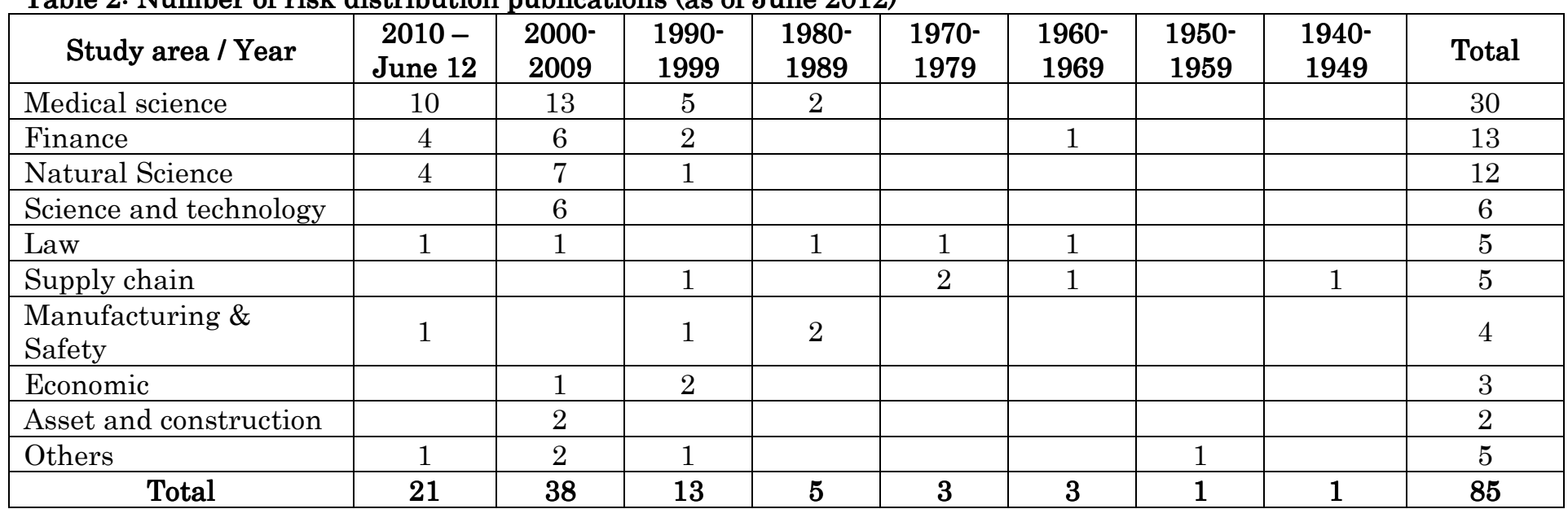

Source: Updated from Yingvilasprasert and Banomyong (2012) [68]

spreading of risk from one distributor to many receivers $[9,31,32,35,38,39,40,41,42,43,44$, $45,46,47]$. However, each observed discipline defined different types of risk and risk receivers. As an example, in medical science the presented risk distribution approach focused on how disease are being distributed among patients or within family members [45, 47, 48]. Additionally, in natural science the risk distribution focused on risk of pollution or contaminant being dispersed among residents within the same territory area [14, 49, 50]. Risk distribution is highly accepted as one effective risk mitigation strategy in finance and the legal disciplines. Both disciplines need to develop risk distribution strategy in order to reduce risk exposure by moving from firms to other parties. Financial risk distribution is often applied to investment projects. In fact, one project may include many investors [35, 51]. Additionally, financial impact sometimes expose by external members. When a project fails, each investor would acquire risk portions based upon their respective financial capability. In the legal field, risks is mostly discussed with liability and ownership [31, 55]. Law cases were found that described the risk distribution phenomenon in terms of characteristics and impacts. Some legal cases claimed that risk responsibility should focus on who is able to pay the most [55].Understanding risk distribution can make risk receivers prepare adequate insurance package in order to cover risk being distributed. Risk distribution is therefore a risk mitigation strategy where the risk distributor reduces its risk exposure by spreading to a number of risk receivers (more than one receiver). Each receiver can have different characteristics and accept certain risk portion based on their risk control ability.In supply chain, only four articles studied issues related to risk distribution as summarized in Table 3 [9, 10, 11, 12].Three articles discussed maritime and transport risks about ownership of liability issues while only one article explained supply chain risk distribution through simulation. These articles identified party who 
should respond for risk occurrence; but still presented a fuzzy picture of risk distribution characteristics in a supply chain related context.

\section{Data Collection and Results}

From the aforementioned section, an exploratory study was conducted to find out conceivable characteristics of risk distribution in supply chains. Exploratory study is most typically conducted for three goals: (1) to desire for better understanding, (2) to test the feasibility of undertaking a more extensive study, and (3) to develop the methods to be employed in any subsequent study [52]. Two target groups were investigated to reflect both theoretical and empirical implications. First, the study was conducted with a number of academic researchers to identify risk distribution from an academic perspective. Second, business practitioners were targeted for empirical support. The following sub-sections will describe sample selection, data collection, and findings; classified by target group.

Table 3: Risk distribution in the supply chain literature

\begin{tabular}{|l|l|l|l|}
\hline \multicolumn{1}{|c|}{ Author (year) } & \multicolumn{1}{|c|}{ Title (Publication) } & \multicolumn{1}{c|}{ Purpose } & \multicolumn{1}{c|}{ Findings } \\
\hline Anonymous (1964) & $\begin{array}{l}\text { When the Lighter "Fades Away," } \\
\text { Who Pays? A Problem in the } \\
\text { Distribution of Maritime Risk } \\
\text { (The Yale Law Journal) }\end{array}$ & $\begin{array}{l}\text { Law cases to identify who } \\
\text { will pay for liability caused } \\
\text { by maritime risk } \\
\text { distribution }\end{array}$ & $\begin{array}{l}\text { Risk distribution effects } \\
\text { in the defining ownership } \\
\text { and liability }\end{array}$ \\
\hline Roberts (1978) & $\begin{array}{l}\text { Common carriers and risk } \\
\text { distribution: absolute liability for } \\
\text { transporting hazardous } \\
\text { materials (Kentucky Law } \\
\text { Journal) }\end{array}$ & $\begin{array}{l}\text { Law cases to identify price } \\
\text { reflection when unavoidable } \\
\text { accidents occurred during } \\
\text { transport of hazardous } \\
\text { materials }\end{array}$ & $\begin{array}{l}\text { Risk distribution theory } \\
\text { is used to distribute cost } \\
\text { of accident to any parties } \\
\text { which mandated the } \\
\text { activity }\end{array}$ \\
\hline Forte (1987) & $\begin{array}{l}\text { Marine insurance and risk } \\
\text { distribution in Scotland before } \\
\text { 1800 (Law and History Review) }\end{array}$ & $\begin{array}{l}\text { Development of marine } \\
\text { insurance in Scotland. }\end{array}$ & $\begin{array}{l}\text { Insurance represent the } \\
\text { most cost effective } \\
\text { method of distributing } \\
\text { maritime risk }\end{array}$ \\
\hline Ji et al., (2009) & $\begin{array}{l}\text { Distribution of Supply Chain } \\
\text { Risk Based on Cooperative } \\
\text { Games (Proceedings of the } \\
\text { International Symposium on } \\
\text { Intelligent Information Systems } \\
\text { and Applications) }\end{array}$ & $\begin{array}{l}\text { Supply chain risk } \\
\text { distribution models based } \\
\text { upon cooperative games are } \\
\text { built and investigate the } \\
\text { impact from different risk } \\
\text { conditions }\end{array}$ & $\begin{array}{l}\text { Different conditions of } \\
\text { cooperative risk increase } \\
\text { or decrease Shapley } \\
\text { value as defined by the } \\
\text { developed model. }\end{array}$ \\
\end{tabular}

Source: Yingvilasprasert and Banomyong (2012)

\section{Risk Distribution in Supply Chains: The Academic Perspective}

The need to theoretically support the concept of risk distribution in the global supply chain requires the study to be conducted with academic researchers $[53,54,55]$. To gather reliable data, the following criteria were chosen: (1) researchers whose known research interest are in supply chain risk management and (2) researchers who have published their papers in peer-reviewed journals. The first criterion was set to scope researchers in the supply chain risk management area. Additionally, any researchers in the second criterion are considered acceptable for high reliability due to the fact that peer-reviewed journal are usually representative of accepted quality of research. Both criteria were used to access researchers' name and e-mail address through university website or academic papers which provided researchers' information. A total of 88 researchers were discovered. However, only 74 researchers could be contacted from their active e-mail address.Open-ended questions were distributed through e-mail. Two main questions were asked: (1) the meaning of risk distribution and (2) the conceivable characteristics of risk distribution. The concept of risk distribution was inferred at this stage by using content analysis. Content analysis is a transparent research method used for longitudinal analysis with relative case. It is an unobtrusive and highly flexible method that can be applied to a wide variety of unstructured information types, as well as method that can be used to provide complex information about the social group [56]. Within a week, the return rate was $28.38 \%$ (21 respondents). All of the responses were Professors and/or Lecturers from academic institutions. From the 21 respondents, three of them could not provide any idea about risk distribution. Thus, only 18 responses were used for further analysis. The results are here presented hereunder. Risk distribution strategy is not understood as the ability to identify liability of ownership as the three reviewed supply chain articles mentioned [9, 10, 11]. Risk distribution was understood by respondents to be a phenomenon of spreading risk 
to capable receivers. Risk distribution strategy was described by respondents as an alternative strategy when risk distributor distributes risk out to secure their business practice. Risk distribution in supply chains does not say explicitly how risk distribution pattern should be. This is because risk that is going to be distributed will first need to be transformed at receiving firms so that risk distributed can be absorbed. Receiving firms can then later decide to distribute the some portion of the received risk to capable receivers. Risk receivers here are not only suppliers but also customers, transporters, insurance company, and other supply chain facilitators. Each receiver may receive a different portion and type of risks in accordance with their performance such as risk control ability, expertise, and trust [57].

Supply chain in Fig. 1 is given to explain risk distribution activity in supply chains.

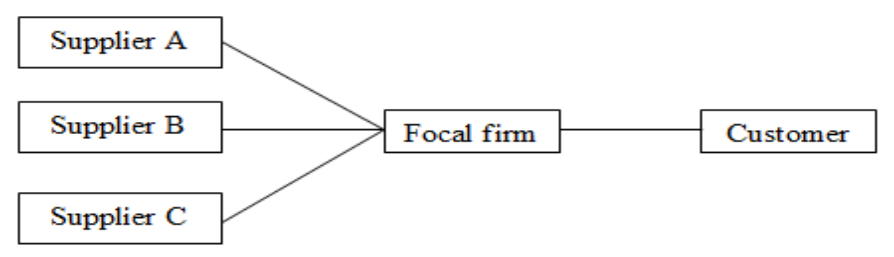

Fig. 1: Supply chain case example

Source: The Authors

Situation: A focal firm gets urgent order from customer (demand risk). However, current production capacity allows firm to only produce $20 \%$ of that order. The focal firm then decides to distribute the rest of the production request out to three suppliers: Supplier A 30\%, Supplier B 40\%, and Supplier C 10\%. In this case, the portion of distributed risk (to each supplier) is based on supplier's production capacity.

The distribution activity is dependent upon the risk distributor judgment and knowledge of risk receiver capability to take such risks. However, each receiver may not have the risk control ability as the risk distributor initially predicted. Risk receivers are also able to further distribute some of the received risk elsewhere. For example, if Supplier A can respond to the distributed order for only $10 \%$, Supplier A can then distribute the rest $20 \%$ to its suppliers (2nd tier suppliers)The aforementioned distribution characteristics explain that risk distribution differs from the other four similar terminologies which were also mentioned by the respondents. The referred terminologies include over-insuring, risk diversification, risk sharing and risk transfer. Each terminology is described as follows.
- Over-insuring is a strategy that allows firm to additionally pay to cover unexpected event [58].

- Risk diversification is a technique which helps to control production risk and price risk. This technique combines portfolio to maintain a relative flow of income and smooth economic situation [59].

- Risk sharing is suggested when firm shares risk among supply chain partners [60]. Firm applies share or investment amount to identify the portion of risk each member responsible to [61].

- Risk transfer introduces the concept where firms push their risks to other supply chain member. The risk transfer concept is applied into two situations: (1) transferring to who is able to reduce the risk and (2) attention to pay for risk, which can outweigh the benefits of efficient allocation [62].

These descriptions were extracted from literature. However, only risk sharing and risk transfer concern activity which relates to giving risk/loss to others. Respondents additionally explained how to distinguish risk sharing and risk transfer from risk distribution as summarized below.In terms of application, risk sharing describes a sharing of business risk among shareholders. Investment portion is used to scope risk responsibility. Relationship is a key element for risk sharing. A good relationship allows everyone to perceive the same picture and thus help altogether minimize risk exposure. Risk sharing is presented as a sound win-win strategy. However, risk handling ability is not pointed out when sharing. Some shareholders might get loss if they do not have enough risk control ability.Risk transfer, in contrast, is less collaborative than risk sharing. Risk transfer describes the activity that hands the risk from one firm to another firm. For example, Manufacturer A encounters production problem. A broken machine reduced $10 \%$ of production capacity (operational risk). Factory manager is concerned from this severe problem and informs to customer. If the customer does not further communicate the situation, this operational risk will be transferred to the consumer. As a result, consumer cannot receive products on time. Risk distribution goes beyond risk sharing and risk transfer. Compared to risk sharing, risk distribution seems to be like a win-lose strategy. Focal firms reduce risk by increasing receiving firms' risk. Risk distribution is more complicated than risk transfer in terms of the number of risk receivers involved. Nevertheless, these three strategies create the same impact through vertical integration activity and the others may get loss. To clearly illustrate, Table 4 hereunder compares three strategies in accordance with the findings from academic perspectives. In practice, risk distribution enhances focal firm performance 
and assures competitive advantage in a long run. Risk distribution helps focal firms who carry too much risk by spreading to other capable risk receivers. Higher capable receivers will surely receive higher risk portions. The next section will further explore risk distribution from business practitioners' perspective in order to increase reliability and validity of the risk distribution concept.

\section{Risk Distribution in Supply Chains: Business Perspective}

The study tested the findings derived from the academic perspective with business practitioners. The authors gathered comments from seven professional experts in supply chain management and risk management. These experts were in high ranking executive position in their respective organizations [63]. Seven participants are usually considered ideal for theory building purpose [64]. Based on accessibility, semi-structured interviews were conducted to discover what risk distribution looked like from their perspective. A semistructured interview is a hybrid of the structured and unstructured approach [65] in which the interviewer commences with a set of interview themes but is prepared to vary the order in which questions are asked and to ask new question in the context of the research situation [66]. In addition, Table 5 identifies each participant against industrial type, business type management style, participant position, and sourcing strategy.All participants were interviewed by telephone for about 30-40 minutes. First, each respondent shortly explained their background and supply chain processes. They additionally identified their level of relationship with suppliers and customers. Second, the respondents explained their perspectives on risks and risk management. Last, the concept of risk distribution was proposed and discussed. The authors interpreted results by grouping the answers into type of industry as hereunder.

Table 4: Comparison between risk distribution, risk sharing and risk transfer

\begin{tabular}{|l|l|l|l|}
\hline \multicolumn{1}{|c|}{ Components } & \multicolumn{1}{|c|}{ Risk distribution } & \multicolumn{1}{c|}{ Risk sharing } & \multicolumn{1}{c|}{ Risk transfer } \\
\hline Rationale to give risk to others & Lack of risk handling ability & Bankruptcy & Property loss \\
\hline Number of risk receivers & Many & Many & One \\
\hline Risk receiver's characteristics & Supplier, Customer, Transporter, etc. & Shareholder & $\begin{array}{l}\text { Insurance } \\
\text { company }\end{array}$ \\
\hline Receivers' criteria & Risk handling ability, trust, etc. & Share proportion & N/A \\
\hline Impacts & Reduce risk in firms while others get impact & $\begin{array}{l}\text { Reduce risk in } \\
\text { firms while } \\
\text { others get } \\
\text { impact }\end{array}$ & $\begin{array}{l}\text { Reduce risk in } \\
\text { firms while } \\
\text { others get } \\
\text { impact }\end{array}$ \\
\hline
\end{tabular}

Source: The Authors

Table 5: Case examples

\begin{tabular}{|l|l|l|l|l|l|}
\hline & Industrial type & \multicolumn{1}{|c|}{ Business type } & \multicolumn{1}{|c|}{$\begin{array}{c}\text { Management } \\
\text { style }\end{array}$} & Participant position & \multicolumn{1}{|c|}{ Sourcing strategy* } \\
\hline Case 1 & Fresh water & Manufacturing & Local & Plant manager & Multiple \\
\hline Case 2 & Tyre & Manufacturing & International & Planning engineer & Multiple \\
\hline Case 3 & Handcraft & Manufacturing & Local & Business owner & Multiple \\
\hline Case 4 & Auto-part & Trading & Local & CEO & Single \\
\hline Case 5 & Tool & Trading & Local & Vice President & Multiple \\
\hline Case 6 & Tyre & Trading & Local & Business owner & Single \\
\hline Case 7 & Logistics & Service & Local & Business owner & Single \\
\hline
\end{tabular}

Source: The Authors; *Multiple sourcing means many suppliers for particular product, Single sourcing means one supplier for particular product

\section{Manufacturing Company}

Manufacturing type of industry is the first group to be discussed. Three respondents under this category consist of two domestic and one multinational company. All of them have a good relationship with their customers and suppliers. Production line is a key business concern for them. Any risks that interrupt production process are considered critical. The two domestic companies have conducted root cause analysis to better understand the impact of production stoppage. Other analytical and mitigation Yingvilasprasert et. al. |July.-Aug. 2012 | Vol.1 | Issue 4|74-84 programs have not been established because of the domestic firms' limited resources such as expertise, manpower capacity, and financial support. In contrast, the multinational firm is subject to mandatory risk management program, established by its headquarter. The program contains risk identification, risk assessment, and risk response activities. Urgent or serious issues are facilitated by headquarter. Risk distribution in supply chains is considered as a new concept for respondents. They are familiar with the concept but only from a financial perspective. The respondents agreed that risk distribution meant 
the spreading of risks or losses from firm (risk distributor) to many risk receivers. This statement was defined and understood similarly to the academic results. Risk distribution can apply to all types of risk in supply chains but the strategy needs to be well executed with specific risks that does not impact future loss such as risk related to know-how (which may increase the number of competitors) and risk related to customer satisfaction (which may reduce customer loyalty). Risk distribution can be done based on two risk receiver characteristics: (1) have ability to control the risk being distributed and (2) have less bargaining power. The first characteristic is due to the fact that each receiver has different risk control ability. Each receiver is capable to manage only certain type and amount of risk depending on their capability. The second characteristic highlights to inherent disadvantage of risk receivers. Risk distributor cannot have success in the strategy if no one accepts the risk being distributed. Bargaining power is one of the key elements used to negotiate with less bargaining parties. Risk distributor may negotiate by handing benefits together with risk such as premium rate. In practice, firms normally distribute risk to suppliers rather than pushing it back to the customer. These two kinds of risk receivers enable a better understanding on how firms maintain relationship through risk distribution scheme.The respondents confirmed that manufacturing companies can utilize risk distribution strategy as there are many potential risk receivers, including, suppliers, customers, facilitators and insurance company. Additionally, a multinational manufacturer indicated that risk distribution is not limited to the use in domestically but also in a global scale. Firm is able to distribute risk to receivers in other countries if they have potential to manage the risk distributed. However, risk distribution strategy needs well organized to reduce conflicts and relationship impacts.

\section{Trading and Service Company}

Trading and service industry is the next group. Three of the trading companies are retailers who receive products from OEM (manufacturer) and sell directly to end customers. The service company is a supply chain facilitator who provides transport and logistics solution. These four companies are similar in the sense that they are domestic small and medium enterprises. Apart from their operational risk, financial risk is their biggest concern. However, their existing risk management program is not seriously implemented because of two main reasons: (1) limited identification of risk involved and (2) low understanding of risk impact on their
business.Nonetheless, even for respondents who have not implemented risk management program, they defined risk distribution as a spreading of risks from firm to many receivers. Risk distribution is considered beneficial when firms do not have enough risk control ability. From the respondents' perspective, it does not make much sense for firm invests in risk management program that focuses on only one risk event. Key characteristics of risk distribution from these respondents focus on the number of risk receivers. If there is only one capable risk receiver, then risk transfer sounds more applicable strategy. Risk transfer can be explained by the following example. A customer purchases the product from a focal firm. If the product is damaged or loss, the manufacturer (focal firm's supplier) will have absorb such risk within guarantee period. This example illustrates risk transferred to supplier.Risk distribution can be applied to all types of risk but can be highly effective under certain conditions such as when the risk does not provide a higher loss. Firms have to carefully justify who will be capable of receiving risk and identify how much each risk receiver should get. Risk receivers are selected from reputation, expertise, and trust in risk mitigation result. In turn, firms provide order commitment and/or incentives to reduce conflict and relationship impact. Attractive incentives also enable risk receiver accept more risks. In addition to the academic perspective, the findings from the business perspective reflect the fact that risk distribution cannot be implemented to every types of business, especially for single sourcing type. In practice, firms prefer to distribute the risk to suppliers because of higher bargaining power. Most suppliers also accept risk from customers' firms because they will use increased risk reception for future negotiation such as order commitment, long term contract, or premium rate.

\section{Conclusion and Suggestions for Future}

\section{Research}

Risk distribution is inferred from the study as to a spread of risk to capable risk receivers. It is an alternative risk management strategy when firms need immediate action but does not have the risk control ability. Risk distribution can be implemented with all kinds of risk that does not result in higher loss when that risk has been distributed. All types of firms can apply risk distribution if they have enough supply chain members distribute risk to. Relationship and mutual benefit must be addressed in order to reduce conflict between parties. Table 6 hereunder summarizes components of risk 
distribution in supply chains. The aforementioned characteristics additionally illustrated that risk distribution is not scoped for any particular use. Unless firms have one capable risk receivers, the findings clearly illustrated without any limitations effect to the practice in global activity such as a precise example from a multinational manufacturer. Any risks can be applied.

\section{Table 6: Elements of risk distribution in supply chains}

\begin{tabular}{|l|l|}
\hline \multicolumn{1}{|c|}{ Element } & \multicolumn{1}{c|}{ Supply chain } \\
\hline Risk originator & Focal firm \\
\hline $\begin{array}{l}\text { Distributed risk } \\
\text { characteristics }\end{array}$ & $\begin{array}{l}\text { Risks which not increase } \\
\text { business impact } \\
\text { Risks which not return future } \\
\text { loss }\end{array}$ \\
\hline Risk receiver & $\begin{array}{l}\text { Suppliers } \\
\text { Customers } \\
\text { Supply chain facilitators } \\
\text { Insurance companies } \\
\text { Transporters } \\
\text { Other supply chain members }\end{array}$ \\
\hline $\begin{array}{l}\text { Risk receiver } \\
\text { characteristics }\end{array}$ & $\begin{array}{l}\text { Lower bargaining power } \\
\text { Capable to manage risk being } \\
\text { distributed }\end{array}$ \\
\hline $\begin{array}{l}\text { Distribution } \\
\text { pattern }\end{array}$ & No fix pattern \\
\hline Distribution impact & $\begin{array}{l}\text { Contractual agreement / } \\
\text { insurance }\end{array}$ \\
\hline
\end{tabular}

Source: The Authors

Any sizes and types of industries are not limited. Risk distribution is therefore a potential alternative risk management in global supply chains.As illustrated by five components in Table 4 , even risk distribution is distinguished from risk sharing and risk transfer but the strategies share the similar chemistry. It is therefore make sense to add risk distribution into a global supply chain risk management framework under the same group as "share/transfer".As far as it can be determined, this is the first study in the field of supply chain management to explore risk distribution strategy from experts. However, this paper is still subject to limitations. The study is limited by its sample size and needs more empirical investigation. As illustrated in Table 7, there are gaps in the literature for six further areas of research: in-depth characteristics of the type of risk being distributed, risk distributor, risk receiver, key drivers, vertical integration, and

\section{Table 7: Research opportunities}

\begin{tabular}{|l|l|}
\hline \multicolumn{1}{|c|}{ Direction areas } & \multicolumn{1}{c|}{ Opportunities for risk distribution study } \\
\hline Risk characteristics & Characteristics of risk being distributed \\
\hline Risk distributor characteristics & Criteria of risk distributor \\
& Situation to distribute the risks \\
& Procurement strategy impact \\
& Industrial practice \\
\hline Risk receiver characteristics & Criteria of risk receivers \\
& Proportion of distributed risk \\
\hline Risk distribution drivers & Key drivers to achieve risk distribution \\
\hline
\end{tabular}

Key drivers to achieve risk distribution risk mitigation results. "Risk characteristics" is the first area of research opportunity. Due to the fact that risk management strategy is highly efficient to particular risk characteristics, choosing the right strategy becomes critical [2]. Most firms selects risk mitigation strategy by considering how much firms can handle or absorb risks. The study still requires further investigation into which risk characteristics should be highlighted to the success of risk mitigation through risk distribution strategy. The second area is "Risk distributor characteristics". Understanding this characteristic is very important because the risk distributor is the person who decides for risk distribution process. It is also necessary to understand which situations should apply risk distribution strategy. From the findings, two characteristics of risk receivers were extracted but they still need to be confirmed. "Risk receiver characteristics" is thus suggested as a third research opportunity. Risk receiver is another important component for the risk distribution process. Without receivers, risk originator or distributors cannot distribute risk out. Risk receivers consist of suppliers, customers, and supply chain facilitators. Without an understanding of risk drivers, firm might encounter obstacles when implementing risk management strategy. In fact, each developed risk distribution strategy depends on different risk drivers or supported elements. Risk distribution strategy then need further investigation related to their relationship with key risk drivers. The question remains whether risk distribution requires a contractual agreement. Contractual agreement actually has both advantages and disadvantages. Its advantage is to ensure that risk receivers know what types of increase risk they are taking on. In contrast, it might allow receivers with the opportunity to reject the risk distribution agreement.Last but not the least in terms of identified research opportunity is related to "Risk mitigation". Risk mitigation is the goal for risk management [2]. Since risk distribution is an alternative strategy, therefore its mitigation result has to be explored.Risk distribution might result in risk reduction or risk elimination either or both for firm and the global supply chain as a whole. 


\begin{tabular}{|l|l|}
\hline Vertical integration & The need of contractual agreement \\
\hline Risk mitigation by risk distribution & Mitigation results \\
& Barrier/obstacle \\
& Advantages and disadvantages against other strategies \\
\hline
\end{tabular}

Source: The Authors

Additionally, risk distribution has to be investigated on how to prevent the distributed risk to return. It was observed that risk distribution cannot be applied to any situations. There is a need for more investigation about barriers and obstacles related to risk distribution strategy. These six research opportunities are suggested to further the understanding the concept of risk distribution. This will enable academia to develop models of risk distribution

\section{References}

1. Waters D (2007) Supply chain risk management: vulnerability and resiliencies in logistics. London, Kogan Page Limited.

2. Manuj I, Mentzer JT (2008) Global supply chain risk management. Journal of Business Logistics 29(1): 133-135.

3. Wagner S, Bobe C (2008) An empirical examination of supply chain performance along several dimensions of risk. Journal of Business Logistics 29(1): 307-325.

4. Juttner U, Peck H., et al. (2003) Supply chain risk management: outlining an Agenda for future research.International Journal of Logistics Management Research \& Application 6(4): 197-210.

5. Brindley C (2004) Supply chain risk. Hampshire, Ashgate Publishing Limited.

6. Pagh JD, Cooper MC (1998) Supply chain postponement and speculation strategies: how to choose the right strategy. Journal of Business Logistics 19(2): 13-33.

7. Ogut H (2005) Information security risk management through self-protection and insurance. Retrieved 20 Jul., 2012, from http://server1.tepper.cmu.edu/seminars/docs/Menon _CyberInsuranceOct27-2005.pdf.

8. Meng C (2009) Multinational banking in China after WTO accession: A Survey. Journal of Financial Regulations and Compliance 17(1): 29-40.

9. Anonymous (1964) When the lighter "fades away" who pays?: a problem in the distribution of maritime risk. The Yale Law Journal 73(4): 717726.

10.Forte ADM (1987) Marine insurance and risk distribution in Scotland before 1800. Law and History Review 5(2): 393-412.

11.Roberts JF (1978) Common carriers and risk distribution: absolute liability for transporting hazardous materials. Kentucky Law Journal 67(2): 441-455. strategies that can then be further tested and validated in real life situation.

\section{Acknowledgement}

The authors would like to acknowledge the partial funding provided by Thailand's Commission for Higher Education (CHE) and Thammasat University under the national target research program.

12.Ji X, Chen W, et al. (2009) Distribution of supply chain risk based on cooperative games. The International Symposium on Intelligent Information Systems and Applications (IISA' 09), Qingdao, P.R. China.

13. Beroll H, Berke O, et al. (2007) Investigating the spatial risk distribution of West Nile virus disease in birds and human in Southern Ontario from 2002 to 2005. Population Health Metrics 5(3): 116.

14. Caballero D, Beltran I, et al. (2007) Forest fires and wildland-urban interface in Spain: types and risk distribution. The IV International Wildfire Conference, Seville, Andalucia.

15. Wu T, Blackhurst J. (2009) Managing supply chain risk and vulnerability: tools and methods for supply chain decision makers. London, SpringerVerlag London Limited.

16. Childerhouse P, Disney SM, et al. (1999) A quick scan method for supply chain diagnostics. The 4th International Symposium on Logistics, Florence.

17. Banomyong, R, Basnet $\mathrm{C}$, et al. (2005) Internationalising the quick scan audit methodology. 18th International Conference on Production Research, Salerno, Italy.

18. Das A, Buddress L (2007) Evaluating prospective e-providers: an empirical study. Journal of Supply Chain Management 43(4): 31-46.

19. Reiner G (2010) Rapid modeling and quick response: intersection of theory and practice. London, Springer-Verlag London Limited.

20. Kahneman D, Tversky A (1979) Prospect theory: an analysis of decision under risk. Econometrica 47(2): 263-291.

21. Cutter SL (1996) Vulnerability to environmental hazards. Progress in Human Geography 20(4): 529-539.

22. Sears MK, Hellmich RL, et al. (2001) Impact of Bt corn pollen on monarch butterfly populations: A 
risk assessment. Proceedings of the National Academy of Sciences of the United States of America 98(21): 11937-11942.

23. Hillson D (2002) What is risk?: towards a common definition. InfoRM, Journal of the UK Institute of Risk Management April: 11-12.

24. Carbone TA, Tippett DD (2004) Project risk management using the project risk FMEA. Engineering Management Journal 16(4): 28-35.

25. Schenerman MA, Axley MJ, et al. (2009) Using a risk assessment process to determine criticality of product quality attributes. Quality by Design for Biopharmaceuticals: Principles and Case Studies. A. S. Rathore and R. Mhatre. New Jersey, John Wiley \& Sons, Inc.

26. Yilmaz K (2009) The risk assessment and prioritization for airport business through the enterprise risk management process. International Journal of Civil Aviation 1(1): 50-61.

27. Peck H (2005) Drivers of supply chain vulnerability: an integrated framework. International Journal of Physical Distribution and Logistics Management 35(4): 210-232.

28. Tranfield D, Denyer D, et al. (2003) Towards a methodology for developing evidence-informed management knowledge by means of systematic review. British Journal of Management 14: 207222.

29. David DA, Thomson MA, et al. (1995) Changing physician performance: a systematic review of the effect of continuing medical education strategies. The Journal of the American Medical Association 274(9): 700-705.

30. Bekelman JE, Li Y, et al. (2003) Scope and impact of financial conflict of interest in Biomedical research. The Journal of the American Medical Association 284(3): 454-465.

31. Steyer RH (1940) Distribution of risk imposed upon corporate officials by federal securities legislation. The Yale Law Journal 39(8): 14211440 .

32. Dowell RS (1986) The distribution of occupational asset risk. Southern Economic Journal 47(2): 463477.

33. Abel T, Wysong JA (1992) Stratification, competition, and risk distribution health insurance in Germany and the United States. Health Insurance 24(4): 240-250.

34. Floater GJ (2001) Habitat complexity, spatial interference, and minimum risk distribution: a framework for population stability. Ecological Monographs 71(3): 447-468.

35. Gao X, Madhavan S, et al. (2001) Applying background risk distribution to evaluate the costeffectiveness of three preventing drug therapies for osteoporotic fractures. Value in Health 4(2): 69-70.
36. Aas K, Dimakos, XK et al. (2007) Risk capital aggregation. Risk Management 9: 82-107.

37. Lindelauf R, Blankers I (2008) On the optimal distribution of risk and information exchange in star networks. The Second International Conference on Computational Cultural Dynamics, College Park, Maryland.

38. Graham RD (1978) Products liability and tort risk distribution in government contract program. Air Force Law Review 20(4): 313.

39. Mendola P, Buck G, et al. (1994) Development disabilities prevention and the distribution of risk among American Indians. American Indian and Alaska Native Mental Health Research 5(3): 3044.

40. Hyatt DE, Pesando JE (1996). The distribution of investment risk in defined benefit pension plans: a reconsideration. Industrial Relations 51(1): 136157.

41. Lejano RP, Davos CA (2002) Fair share: siting noxious facilities as a risk distribution game under nontransferable utility. Journal of Environmental Economics and Management 43(2): 251-266.

42. Waldhor T, Schober E (2003) Regional distribution of risk for childhood diabetes in Austria and possible association with body mass index. European Journal of Pediatrics 162(6): 380-384.

43. Hallikas J, Karvonenb I, et al. (2004) Risk management process in supplier network. International Journal of Production Economics 90: 47-58.

44. Hay SI, Guerra CA, et al. (2004) The global distribution and population at risk of Malaria: past, present, and future. The Lancet Infectious Disease 4: 327-473.

45. Norozi K, Wessel A, et al. (2006) Incidence and risk distribution of heart failure in adolescents and adults with congenital heart disease after cardiac surgery. The American Journal of Cardiology 97(8): 1238-1243.

46. Chokevivat V, Limwattananon S, et al. (2007) Health risk distribution by socio-economic status and educational levels of Thai households: who smoke and drink more? Journal of Health Science: 3-19.

47. Qian H, Lia Y, et al. (2009) Spatial distribution of infection risk of SARS transmission in a hospital ward. Building and Environment 44(8): 16511658.

48. Gerbershagen K, Gerbershagenb HU, et al. (2009) Prevalence and risk distribution among inpatients in a German teaching school. The Clinical Journal of Pain 25(5): 431-437.

49. Yamoah CF, Walters DT, et al. (2000) Standardised precipitation index and nitrogen rate effects on crop yields and risk distribution in maize. Agriculture, Ecosystems and Environment 80(1-2): 113-120. 
50. Jiang ZJ, Fang JG, et al. (2008) Distribution features and evaluation on potential ecological risk of heavy metals in surface sediments of Sungo bay. Journal of Agro-Environment Science 27(1): 301-305.

51. Andreou E, Ghysels E (2002) Quality control for financial risk management: monitoring disruptions in the distribution of risk exposure, University of Cyprus/ University of North Carolina.

52. Babbie E (2007) The practice of social research. CA, Wadsworth.

53. Christine MH, Richard CL, et al. (1999) Developing the concept of supply strategy. International Journal of Operations and Production Management 19(7): 650-674.

54. Steve VW, Jatinder NDG (1999) Electronic data interchange for process change in an integrated supply chain. International Journal of Operations and Production Management 19(4): 372-388.

55. Douglas ML, Martha CC (2000) Issues in supply chain management. Industrial Marketing Management 29: 65-83.

56. Bryman A, Bell E (2007) Business Research Methods Oxford, Oxford University Press.

57. Fugate BS, Mentzer JT, et al. (2009). Logistics performance: efficiency, effectiveness, and differentiation. Journal of Business Logistics 31(1): 43-62.

58. Stadtliaus KR (1960) Method of staking blades. United State Patent Office July.

59. Featherstone AM, Moss CB (1990) Quantifying gains to risk diversification using certainty equivalence in a mean-variance model: an application to Florida citrus. Southern Journal of Agricultural Economics 12: 191-197.

60. Juttner U (2005) Supply chain risk management: understanding the business requirements from a practitioner perspective. International Journal of Logistics Management 16(1): 120-141.

61. Pratt JW, Zeckhauser RJ (1989) The impact of risk sharing on efficient decision. Journal of Risk and Uncertainty 2: 219-234.

62. Hall M, Holt R, et al. (2000) Private finance, public roads: configuring the supply chain in PFI highway construction. European Journal of Purchasing and Supply Management 6: 227-235.

63. Smith ME (2009) Psychological foundations of supply chain risk management. International Series in Operations Research and Management Science 124(3): 219-233.

64. Eisenhardt KM (1989) Building theories from case study research. Academy of Management Review 14(4): 532-550.

65. Wilson J (2010) Essentials of business research: a guide to doing your research project. London, SAGE Publications, Inc.

66. Saunders M, Lewis P, et al. (2007) Research methods for business students. Essex, Prentice Hall.

67. Calabresi G (1961) Some thoughts on risk distribution and the law of torts. The Yale Law Journal 70(4): 499-553.

68. Yingvilasprasert M, Banomyong R (2012) Conceptualising risk distribution for supply chain sustainability. International Journal of Agile Systems and Management 5(1): 82-102. 